\begin{tabular}{lr}
\hline Jurnal Abdimas llmiah & JURNAL ABDIMAS ILMIAH CITRA BAKTI \\
Citra Bakti & Volume 2, Nomor 2, November 2021 \\
$(\mathrm{JAICB})$ & \\
\hline
\end{tabular}

\title{
PENDAMPINGAN PEMBELAJARAN ANAK PADA MASA PANDEMI COVID-19 BERBASIS VIDEO PEMBELAJARAN TEMATIK DI TKK ST. SKOLASTIKA MATAIA
}

\author{
Efrida (ta1), Andi Nafsia'), Monika Kolo ${ }^{3)}$, Maria Christina Rona ${ }^{4)}$, Bernadeta Lawo ${ }^{5}$, \\ Priska A.M.T. Lopes ${ }^{6}$, Maria Audensia Wunu'), Maria Magdalena Bupu ${ }^{8)}$, Maria Anjelina \\ $\mathrm{Ule}^{9)}$, Ancelina Bao Wea ${ }^{10)}$, Maria Elenora Debo ${ }^{11)}$, Maria Florensiana Dopo ${ }^{12)}$ \\ 1,2,3,4,5,6,7,8,9,10,11,12)Program Studi PGPAUD, STKIP Citra Bakti \\ ${ }^{1)}$ evoletelvo@gmail.com, \\ 2)andinafsia89@gmail.com,${ }^{3}$ monikakolo205@gmail.com, ${ }^{4}$ )mariachristinarona@gmail.com, \\ 5)bernadetalawo@gmail.com, 6)priskalopes97@gmail.com, ${ }^{7}$ mariaaudensiawunu@gmail.com, \\ 8)magdalena.bupu99@gmail.com, ${ }^{9}$ mariaanjelinaule99@gmail.com, ${ }^{10}$ Mariaelenoradebo97@gmail.co \\ $\underline{\mathrm{m}},{ }^{11}$ mariaflorensianadopo@gmail.com, ${ }^{12)}$ ancelinabaowea@gmail.com
}

\begin{tabular}{l} 
Histori artikel \\
\hline Received: \\
14 November 2021 \\
Accepted: \\
26 November 2021 \\
Published: \\
30 November 2021
\end{tabular}

\begin{abstract}
Abstrak
Kegiatan pengabdian kepada masyarakat yang dilakukan oleh dosen dan mahasiswa terdiri dari beberapa jenis kegiatan. Salah satu dari kegiatankegiatan tersebut adalah Kuliah Kerja Nyata (KKN). Kegiatan KKN yang dilakukan guna meningkatkan atau memperluas pengetahuan mahasiswa, melatih mahasiswa untuk menerapkan secara konkrit teori yang sudah dipelajari mahasiswa di tengah masyarakat, menjadikan mahasiswa tanggap dan resolutif dalam menanggapi isu atau permasalahan yang timbul di masyarakat apalagi ditengah merebaknya wabah covid-19 yang membawa perubahan besar dalam bidang kehidupan manusia, tak terkecuali bidang pendidikan anak usia dini. Hal yang paling menonjol adalah proses pembelajaran yang harus dilakukan secara daring demi mencegah dan memutus mata rantai penyebaran covid-19. Salah satu program yang dilakukan dalam kegiatan KKN adalah membuat atau menghasilkan video pembelajaran berbasis tematik guna meningkatkan perkembangan belajar anak dengan tujuan untuk: 1) meningkatkan minat dan motivasi belajar anak, 2) menjadi bahan referensi guru dalam mengembangkan pembelajaran yang inovatif melalui jaringan (daring), 3) membantu mengembangkan aspek perkembangan anak. Metode pelaksanaan dilakukan melalui ceramah, wawancara dan demostrasi. Hasil dari kegiatan pengabdian ini adalah dengan video pembelajaran berbasis tematik yang dihasilkan dapat membantu guru dalam melaksanakan proses pembelajaran di masa pandemi guna mengoptimalkan perkembangan belajar anak di TKK St. Skolastika Mataia.
\end{abstract}

Kata-kata Kunci: pendampingan belajar anak, video pembelajaran tematik 
Abstract. Community service activities carried out by lecturers and students consist of several types of activities. One of these activities is the community service internship. Community service activities are carried out to increase or expand students' knowledge, train students to apply concretely the theories that students have learned in the community, make students responsive and resolutive in responding to issues or problems that arise in the community, especially in the midst of the outbreak of the covid-19 outbreak that has brought changes in the field of human life, including the field of early childhood education. The most prominent thing is the learning process that must be done online in order to prevent and break the chain of the spread of covid-19. One of the programs carried out in community service internship activities is to create or produce thematic-based learning video to improve children's learning development with the aim of: 1) increasing children's interest and motivation in learning, 2) becoming teacher reference materials in developing innovative learning through networks (online), 3) help develop aspects of child development. The implementation method is done through lectures, interviews and demonstrations. The result of this service activity is that the thematically based learning videos produced can assist teachers in carrying out the learning process during the pandemic in order to optimize children's learning development at St. Scholastica Mataia kindergarten.

Keywords: children's learning assistance, thematic learning video

\section{PENDAHULUAN}

Dalam Undang-Undang Nomor 20 tahun 2003 tentang Sistem Pendidikan Nasional dikatakan bahwa pendidikan anak usia dini merupakan usaha sadar dan terencana untuk mewujudkan suasana belajar dan proses pembelajaran agar peserta didik secara aktif dapat mengembangkan potensi dirinya agar memiliki kekuatan spiritual keagamaan, pengendalian diri, kepribadian, kecerdasan, akhlak mulia dan keterampilan yang dimiliki yang berguna bagi dirinya, masyarakat, bangsa dan negara serta memiliki kesiapan untuk memasuki pendidikan lebih lanjut. Isi Undang-Undang ini menegaskan bahwa potensi anak perlu dikembangkan melalui pendidikan khususnya pendidikan anak usia dini sehingga di jenjang pendidikan yang lebih tinggi anak memiliki dasar kuat untuk mengikuti proses pembelajaran.

Masa usia dini merupakan masa yang paling potensial bagi perkembangan anak atau biasa disebut dengan istilah golden age. Masa ini merupakan masa terbentuknya dasar bagi diri anak yang akan menentukan kehidupannya di tahap selanjutnya. Anak harus dibekali dengan pengetahuan dan stimulus yang cukup sehingga perkembangannya terpantau maksimal. Seperti yang diungkapkan oleh Ita (2018: 45) bahwa masa-masa ini adalah masa yang tepat untuk meletakkan dasar-dasar pengembangan fisik, bahasa, sosial emosional, konsep diri, seni, moral dan nilai-nilai agama. Anak usia dini merupakan anak yang sedang dalam tahap pertumbuhan dan perkembangan, baik fisik maupun mental yang paling pesat.

Merebaknya wabah virus covid-19, mengakibatkan perubahan yang signifikan bagi seluruh sektor kehidupan manusia. Salah satunya adalah sektor pendidikan. Perubahan besar yang tampak dalam proses pendidikan adalah beralihnya sistem pembelajaran tatap muka ke sistem pembelajaran dalam jaringan (daring). Hal ini berlaku untuk semua jenjang pendidikan, tak terkecuali lembaga Pendidikan Anak Usia Dini (PAUD). Perubahan sistem pembelajaran ini menjadi hal yang krusial, baik bagi sekolah maupun orang tua anak.

Penyelenggaraan layanan pendidikan anak usia dini yang dilakukan secara daring atau online menimbulkan masalah khususnya pelaksanaan pembelajaran bagi anak usia dini, 
karena anak tidak dapat belajar sendiri tanpa adanya pengawasan baik dari guru maupun orang tua. Kebijakan pemerintah yang mencanangkan program belajar dari rumah tidak serta merta meredupkan kreativitas dan profesionalisme guru dalam menjalankan tugasnya. Justru dimasa seperti inilah guru harus semakin bertanggungjawab dalam meningkatkan kompetensi yang dimiliki agar tetap melakukan bimbingan belajar dan memberikan penilaian terhadap aspek perkembangan anak.

Salah satu cara yang dapat dilakukan oleh guru untuk mengoptimalkan pembelajaran secara daring adalah melalui pembuatan video pembelajaran bagi anak. Dalam hal ini, guru juga harus menjalin komunikasi dan kerja sama yang harmonis dengan orang tua sehingga dapat mendukung kelancaran proses pembelajaran bagi anak. Dalam menyelenggarakan pembelajaran secara daring guru harus tetap mengacu pada RPPM dan RPPH yang termuat dalam Kurikulum 2013 dengan menggunakan pendekatan tematik terpadu, yang berarti setaip minggu dan setiap hari sudah terorganisir kompetensi apa saja yang harus dicapai melalui pembelajaran tematik terpadu.

Berdasarkan hasil observasi dan wawancara yang dilakukan di TKK St. Skolastika mulai memberlakukan proses pembelajaran secara tatap muka yang terbagi menjadi 4 kelompok dengan tetap memperhatikan protokol kesehatan. Pada saat proses bimbingan belajar yang dilakukan dan ditemukan beberapa masalah perkembangan anak dan berkesimpulan bahwa anak didik mengalami banyak kesulitan saat proses pembelajaran berlangsung antara lain anak lambat dalam memberikan respon terhadap materi yang disampaikan oleh guru, anak kesulitan saat diminta untuk mengikuti apa yang diucapkan oleh guru, adapula anak yang memberikan respon dengan kata-kata yang diucapkan oleh guru seperti disaat guru mengucapkan "selamat pagi anak-anak" anak tersebut memberikan respon sama dengan yang diucapkan oleh guru.

Dari hasil wawancara yang telah dilakukan oleh guru dikatakan bahwa proses perkembangan anak seperti yang dipaparkan di atas, dikarenakan anak bersekolah satu minggu sekali sesuai dengan pembagian kelompok yang terdiri dari 5 anak dalam satu kelompok. Kesulitan yang dialami anak merupakan salah satu akibat dari pembelajaran yang dilaksanakan dengan sistem pembagian kelas. Hal ini tentu akan berdampak buruk pada kualitas perkembangan dan hasil belajar anak. Disisi lain, waktu pembelajaran yang kurang efektif juga memiliki pengaruh buruk bagi berlangsungnya proses mentransmisikan materi dari guru kepada anak didik.

Berbagai penyimpangan yang ditemukan menunjukkan bahwa anak tidak dapat berkembang secara optimal. Namun hal tersebut tidaklah seharusnya menjadi momok yang menakutkan melainkan semakin mendorong daya juang guru agar perkembangan anak tercapai secara optimal. Salah satu cara yang dapat dilakukan adalah dengan melakukan pendampingan belajar menggunakan video pembelajaran tematik agar dapat diberikan 
kepada anak, baik saat sesinya mereka di sekolah maupun saat mereka di rumah, agar dapat mengulangi materi yang sudah dipelajari.

Les Giblin dalam bukunya Skill With People mengatakan bahwa dalam kesehariannya, manusia belajar $83 \%$ melalui penglihatan, $11 \%$ melalui pendengaran, 3,5\% melalui penciuman, 1,5\% melalui sentuhan dan 1\% melalui rasa (Giblin, 2005, p.1). Berdasarkan teori ini, dapat disimpulkan bahwa dalam kegiatan belajar mengajar media pembelajaran yang efektif sangat dibutuhkan melalui indera penglihatan dan pendengaran. Oleh karena itu, video pembelajaran merupakan salah satu media yang direkomendasikan dan dinilai cukup efektif dalam pembelajaran anak usia dini.

Berdasarkan penelitian yang dilakukan oleh Luh Made Indria Dewi dan Ni Luh Rimpiati, melalui penggunaan media pembelajaran berupa video interaktif dinilai dapat menghubungkan perkembangan kognitif, emosional dan psikomotorik anak. Dengan video dapat memberikan fleksibilitas pada guru sekaligus mempelajari psikomotorik anak. Menurut Luh Made Indria Dewi dan Ni Luh Rimpiati (Dewi \& Rimpiati, 2015) dengan menggunakan video pembelajaran dapat membuat pembelajaran lebih efektif. Hal serupa juga ditemukan dalam penelitian yang dilakukan oleh Lely Suryani yang berkesimpulan bahwa menggunakan video sebagai media pembelajaran dapat meningkatkan perilaku cinta lingkungan setelah anak menonton video pembelajaran dengan persentase sebesar $45 \%$ (Suryani \& Seto, 2020).

Disisi lain penelitian yang dilakukan oleh Imam Syafi'i dan kawan-kawan, menyatakan bahwa penerapan video pembelajaran daring anak usia dini pada masa pandemi covid-19 dinilai cukup efektif karena dapat meningkatkan minat dan perhatian anak-anak di rumah, sehingga semakin terdorong munculnya motivasi belajar dalam diri anak yang tentu saja berdampak positif bagi perkembangan belajar anak.

Video pembelajaran tematik yang dibuat haruslah tetap memperhatikan prinsip dasar pembelajaran anak usia dini dan memiliki tujuan untuk meningkatkan minat dan motivasi anak untuk belajar serta menjadi bahan referensi bagi guru dalam menyikapi persoalan yang mungkin timbul. Materi yang disajikan dalam video pembelajaran merupakan materi yang dibelajarkan pada anak yang dirancang sesuai dengan kompetensi inti dan kompetensi dasar yang termuat dalam Permendiknas No. 137 tahun 2014 tentang Standar Tingkat Pencapaian Perkembangan Anak (STPPA).

Berdasarkan pemaparan diatas, maka perlu untuk dilakukan kegiatan pengabdian kepada masyarakat dengan judul "Pendampingan Pembelajaran Anak pada Masa Pandemi Covid-19 Berbasis Video Pembelajaran Tematik Di TKK St. Skolastika Mataia.“

\section{METODE PELAKSANAAN}

Pembuatan video pembelajaran berbasis tematik dalam kegiatan pengabdian pada masyarakat desa Waeia yang dikhususkan bagi anak usia dini di TKK St. Skolastika bertujuan 
untuk meningkatkan minat dan motivasi belajar anak serta menjadi bahan referensi guru dalam menghasilkan pembelajaran yang kreatif dan inovatif. Langkah-langkah kegiatan pengabdian antara lain:

1) Melakukan pendekatan dengan pemerintah desa Waeia dalam rangka melakukan konsultasi dengan pihak sekolah

2) Melakukan survei lokasi sebelum bimbingan belajar dan didokumentasikan

3) Melakukan pendekatan dengan Ibu Ani selaku kepala TKK St. Skolastika Mataia

4) Melakukan kunjungan ke sekolah sekaligus pengamatan awal dalam bimbingan belajar

5) Menyiapkan materi pembelajaran yang akan disajikan dalam bentuk video pembelajaran berbasis tematik

6) Membuat video pembelajaran tematik terpadu

7) Hasilnya didokumentasi dengan baik sebagai bukti pelaksanaan kegiatan pengabdian pada masyarakat

Dalam kegiatan pengabdian ini, TKK St. Skolastika berperan sebagai narasumber dalam proses pengumpulan data yang diperlukan dalam membuat video pembelajaran tematik. Tim pengabdi dalam melaksanakan kegiatan bimbingan belajar didampingi oleh guru kelas sesuai dengan jadwal yang sudah ditentukan. Sasaran dari kegiatan pengabdian pada masyarakat ini adalah guru dan anak didik di TKK St. Skolastika Mataia. Kegiatan pengabdian ini diselenggarakan dengan melibatkan bantuan dari beberapa pihak yakni pemerintahan desa Waeia, tenaga pendidik, tenaga kependidikan TKK St. Skolastika Mataia dan dosen pendamping.

Teknik pengumpulan data yang digunakan pada kegiatan pengabdian ini adalah observasi, wawancara dan dokumentasi. Observasi merupakan teknik pengumpulan data dengan menggunakan pengamatan secara langsung maupun tidak langsung (Riyanto, 2010). Observasi dilakukan melalui kunjungan ke TKK St. Skolastika Mataia. Merebaknya wabah Covid-19, membuat proses pembelajaran dilaksanakan menggunakan pembagian dengan 5 anak dalam satu hari pembelajaran, sedangkan wawancara merupakan teknik pengumpulan data dengan berkomunikasi langsung antara penyelidik dengan subjek atau responden (Riyanto, 2010). Dalam pengabdian ini, tim melakukan wawancara dengan guru di TKK St. Skolastika Mataia. Dokumentasi dalam kegiatan pengabdian ini adalah dengan melihat dokumen-dokumen pendukung pembelajaran seperti RPPM dan RPPH serta foto-foto kegiatan bimbingan belajar yang dilakukan di sekolah dan video pembelajaran berbasis tematik.

Metode pembelajaran yang digunakan guna mendukung keberhasilan program ini antara lain:

1) Ceramah 
Metode ceramah dipilih sebagai cara untuk mentransmisikan pesan atau informasi berupa materi pelajaran guna menambah wawasan pengetahuan anak dalam belajar. Dalam pembuatan video pembelajaran metode ini nampak saat guru memaparkan materi sesuai dengan tema yang sudah ditentukan. Sasaran utama dalam metode ini adalah anak didik di lembaga pendidikan TKK St. Skolastika Mataia.

2) Demonstrasi

Metode ini dipilih untuk memperjelas dan memperagakan apa yang disampaikan. Karena pada dasarnya anak usia dini mempelajari sesuatu dengan meniru (imitation), maka dari itu metode demonstrasi sangat cocok untuk diterapkan dalam program pengabdian ini. Dalam pembuatan video pembelajaran tematik, metode ini tampak saat guru memperagakan apa yang sudah dijelaskan disertai dengan gambar pendukung.

\section{HASIL DAN PEMBAHASAN}

\section{Hasil}

Pelaksanaan kegiatan pengabdian ini dilakukan secara terintegrasi dengan program lainnya di desa Waeia yang melibatkan 10 mahasiswa program studi PG-PAUD dan 2 orang dosen pendamping dari STKIP Citra Bakti, 18 anak didik dari TKK St. Skolastika Mataia. Selain itu kepala sekolah dan guru serta dosen juga memberikan bantuan dan masukan kepada mahasiswa jika ditemukan kesulitan saat melakukan bimbingan Waktu yang digunakan dalam penyelenggaraan program ini sebanyak 2 kali pertemuan dengan alokasi waktu kurang lebih 2 jam. Hal ini tentu saja tidak efektif untuk melakukan pengabdian secara lebih kompleks. Namun berdasarkan hasil pengamatan dan wawancara yang sudah dilakukan, ditemukan adanya kesulitan dalam perkembangan belajar anak.

Sebelum membuat video pembelajaran berbasis tematik, terlebih dahulu tim melakukan kunjungan ke sekolah. Berikut adalah gambar kegiatan kunjungan dan bimbingan belajar di sekolah.

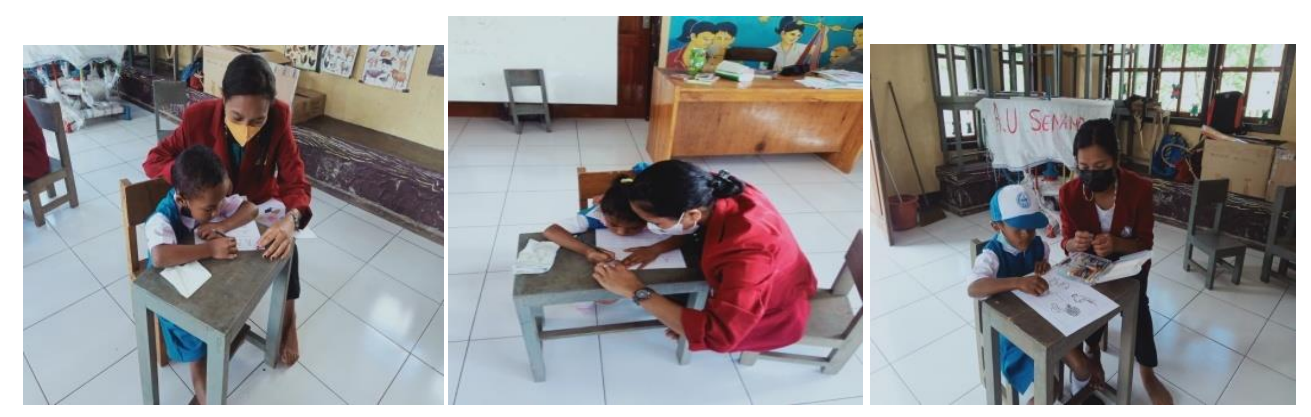

Berikut adalah contoh gambar hasil video pembelajaran berbasis tematik yang sudah dibuat. 


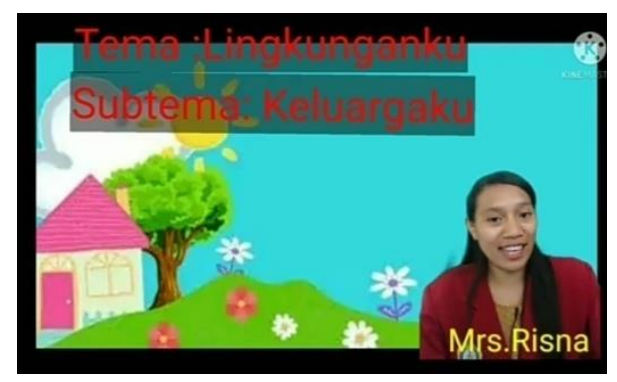

Gambar 1.Hasil video pembelajaran

Sumber: https://youtu.be/CU1OWhs_ckM

\section{Pembahasan}

Pandemi covid-19 membawa perubahan besar-besaran dalam semua bidang kehidupan manusia tak terkecuali untuk semua jenjang dalam bidang pendidikan. Pendidikan anak usia dini merupakan salah satu jenjang pendidikan yang terdampak covid-19. Pentingnya pendidikan bagi anak usia dini adalah agar anak dapat menyelesaikan tugas-tugas perkembangannya dan dapat meningkatkan pertumbuhan dan perkembangan anak secara optimal.

Dampak dari pandemi covid-19 bagi dunia pendidikan diantaranya peserta didik mengalami keterpaksaan dalam melaksanakan proses pembelajaran tanpa sarana dan prasarana yang memadai di rumah, tidak ada aktivitas di sekolah dalam waktu lama yang mengakibatkan peserta didik jenuh, harus punya biaya tambahan untuk membeli kuota dan keterampilan guru semakin dituntut dalam beradaptasi menggunakan teknologi dan kepemilikan sarana dan prasarana yang memadai (Purwanto et al., 2020, p. 9).

Dalam Surat Edaran Nomor 4 Tahun 2020 tentang Pelaksanaan Kebijakan Pendidikan dalam Masa Darurat Penyebaran Covid-19 yang ditetapkan oleh Menteri Pendidikan dan Kebudayaan Republik Indonesia pada poin kedua memuat:

1) Belajar dari rumah melalui pembelajaran daring atau jarak jauh dilaksanakan untuk memberikan pengalaman belajar yang bermakna bagi peserta didik tanpa terbebani tuntutan menuntaskan seluruh capaian kurikulum untuk kenaikan kelas maupun kelulusan.

2) Belajar dari rumah dapat difokuskan pada pendidikan kecakapan hidup antara lain cara yang dapat dilakukan atau diterapkan dalam menanggulangi dan mencegah covid-19.

3) Aktivitas dan tugas pembelajaran dari rumah dapat bervariasi antarsiswa, sesuai dengan minat dan kondisi masing-masing termasuk mempertimbangkan kesenjangan akses atau fasilitas belajar dari rumah.

4) Bukti atau produk aktivitas belajar dari rumah diberi umpan balik yang bersifat kualitatif dan berguna dari guru tanpa harus memberikan skor atau nilai kuantitatif.

Proses pembelajaran yang semula dilakukan secara tatap muka mengalami pergeseran menjadi proses pembelajaran secara dalam jaringan (daring). Hal ini dilakukan 
sesuai dengan regulasi yang ditetapkan oleh pemerintah. Kebijakan pemerintah yang mencanangkan program belajar dari rumah sudah diterapkan oleh lembaga pendidikan anak usia dini di TKK St. Skolastika Mataia. Hal ini tidak serta merta meredupkan kreativitas dan profesionalisme guru dalam menjalankan tugasnya. Justru dimasa seperti inilah guru harus semakin bertanggungjawab dalam meningkatkan kompetensi yang dimiliki agar tetap melakukan bimbingan belajar dan memberikan penilaian terhadap aspek perkembangan anak.

Salah satu cara yang dapat dilakukan untuk mengoptimalkan pembelajaran yang dilakukan secara daring adalah dengan memanfaatkan teknologi digital yang bermanfaat mengubah cara berkomunikasi dan mengubah cara otak bekerja dengan cepat dan mendalam agar proses pembelajaran tetap berjalan.

Pada masa pandemi seperti ini guru dituntut untuk melek dalam menggunakan teknologi hasil revolusi industri yang dapat dilihat dalam keseharian guru dihadapkan pada platform dan alat digital yang dapat mentransmisikan materi pembelajaran dengan mudah. Berbekal latihan mandiri guru mampu melakukan peralihan dari kegiatan tatap muka ke pembelajaran berbasis online atau daring. Menurut Fullan dalam Ruth McQuirter, banyak guru yang masih mengalami kesulitan dalam hal berurusan dengan teknis penyampaian dan tidak dapat mengajukan pertanyaan yang dapat merupakan umpan balik dalam meningkatkan perkembangan kognitif, sosial dan emosional anak-anak di lingkungan (McQuirter, 2020, p. 49). Berbagai aplikasi dapat digunakan oleh guru selama proses pembelajaran yang dilakukan secara daring diantaranya Google Classroom, Google Meet, YouTube dan Whatsapp. Namun dalam mengaplikasikannya masih banyak yang mengalami kesulitan karena belum terbiasa. Disisi lain guru juga tetap harus menggunakan media pembelajaran.

Media pembelajaran merupakan alat atau sarana yang digunakan untuk menyampaikan informasi dari pengirim kepada penerima pesan yang dapat merangsang perhatian, perasaan, pikiran dan minat peserta didik agar dapat terjadinya proses pembelajaran (Mawarti, 2018, p. 13). Pemanfaatan media pembelajaran bertujuan untuk memudahkan peserta didik dalam memahami hal yang disampaikan oleh guru dan dapat memotivasi anak untuk belajar, meningkatkan efektivitas dan efisiensi pembelajaran. Media yang digunakan dikelompokkan menjadi tiga yakni media visual, media audio dan media audio visual. Media visual merupakan media yang hanya menampilkan gambar atau tulisan sedangkan media audio merupakan media yang menampilkan informasi berupa pesan auditif atau yang hanya dapat didengar. Media audiovisual merupakan media hasil kombinasi dari media audio dan media visual yang menyajikan informasi dalam bentuk gambar dan suara.

Salah satu media audiovisual yang bisa digunakan adalah video pembelajaran berbasis tematik. Dengan bantuan media ini akan ditampilkan animasi, gambar dan audio yang dapat membantu anak agar lebih fokus belajar dan guru juga lebih percaya diri dalam 
menyampaikan materi pelajaran. Guru membuat video pembelajaran yang akan dibagikan kepada anak. Dalam hal ini, guru juga harus menjalin komunikasi dan kerja sama yang harmonis dengan orangtua sehingga dapat mendukung kelancaran proses pembelajaran bagi anak.

Pembuatan video pembelajaran berbasis tematik ini bertujuan untuk meningkatkan minat dan motivasi anak dalam belajar yang tentu saja harus disesuaikan dengan kondisi nyata yang ditemukan di lapangan. Pendekatan pembelajaran yang tepat pada anak usia dini akan menentukan keberhasilan anak dalam mencapai perkembangan yang optimal sesuai dengan karakteristik, minat dan bakat anak yang sesuai dengan lingkup pembelajaran PAUD yang meliputi seluruh aspek perkembangan anak yakni nilai agama dan moral, fisik motorik, kognitif, bahasa, sosial emosiona dan seni.

Ada beberapa hal yang harus diperhatikan oleh guru dalam menggunakan video pembelajaran, yakni:

1) Guru harus mempersiapkan materi yang akan disampaikan terlebih dahulu, kemudian baru memilih media video yang tepat untuk mencapai tujuan pengajaran yang diharapkan.

2) Guru harus memperhatikan durasi video.

3) Memperhatikan penjelasan global terkait isi video dan persiapan peralatan yang akan digunakan untuk memperlancar proses pembelajaran.

4) Video pembelajaran yang disajikan harus mampu memotivasi anak untuk mempelajari kegiatan dan pengetahuan yang ada didalamnya.

5) Video pembelajaran yang dibuat semestinya dapat meningkatkan, menunjang aktivitas pembelajaran dan mampu memfasilitasi anak dalam mencapai aspek perkembangan secara optimal.

Dalam melaksanakan kegiatan ini digunakan pendekatan yang digunakan dalam kurikulum 2013, yakni melalui pendekatan tematik terpadu. Dalam model ini, proses pembelajaran yang diterapkan pada anak usia dini dilakukan untuk satu tema, sub tema dan sub-sub tema yang dirancang dalam RPPH agar dapat mencapai tujuan pembelajaran yakni meningkatkan perkembangan anak pada kompetensi sikap, pengetahuan dan keterampilan dan juga seluruh aspek perkembangan anak secara terintegrasi.

Pada kegiatan pengabdian ini, tim mengaplikasikan melalui pembelajaran yang bersifat tidak langsung atau pembelajaran dalam jaringan (daring) yang tidak dirancang khusus, namun memiliki andil dalam meningkatkan perkembangan belajar anak. Melalui pembelajaran daring diharapkan dapat mencapai kompetensi pengetahuan dan keterampilan yang nantinya akan berdampak juga pada pengembangan sikap spiritual dan sikap sosial. Oleh karena itu, maka tim pengabdian masyarakat program studi PG-PAUD Sekolah Tinggi Keguruan dan IImu Pendidikan Citra Bakti melakukan bimbingan belajar berbasis video pembelajaran tematik pada masa pandemi ini. Penyelenggaraan kegiatan ini disesuaikan dengan Rencana 
Pelaksanaan Pelajaran Mingguan (RPPM) dan Rencana Pelaksanaan Pembelajaran Harian (RPPH) yang ada di TKK St. Skolastika Mataia.

Dengan adanya video pembelajaran berbasis tematik ini sangat berguna dalam membantu guru untuk membelajarkan anak pada masa pandemi dan juga dapat meningkatkan minat serta motivasi anak dalam belajar. Hal ini sesuai dengan penelitian yang dilakukan oleh Luh Made Indria Dewi dan Ni Luh Rimpiati, melalui penggunaan media pembelajaran berupa video interaktif dinilai dapat menghubungkan perkembangan kognitif, emosional dan psikomotorik anak. Dengan video dapat memberikan fleksibilitas pada guru sekaligus mempelajari psikomotorik anak. Menurut Luh Made Indria Dewi dan Ni Luh Rimpiati (Dewi \& Rimpiati, 2015) dengan menggunakan video pembelajaran dapat membuat pembelajaran lebih efektif. Hal serupa juga ditemukan dalam penelitian yang dilakukan oleh Lely Suryani yang berkesimpulan bahwa menggunakan video sebagi media pembelajaran dapat meningkatkan perilaku cinta lingkungan setelah anak menonton video pembelajaran dengan persentase sebesar $45 \%$ (Suryani \& Seto, 2020).

Disisi lain penelitian yang dilakukan oleh Imam Syafi'i dan kawan-kawan, menyatakan bahwa penerapan video pembelajaran daring anak usia dini pada masa pandemi covid-19 dinilai cukup efektif karena dapat meningkatkan minat dan perhatian anak-anak di rumah, sehingga semakin terdorong munculnya motivasi belajar dalam diri anak yang tentu saja berdampak positif bagi perkembangan belajar anak.

Sebagai bagian dalam kegiatan pengabdian ini, tentu saja tim harus menghasilkan luaran. Adapun luaran dari kegiatan ini adalah menyajikan video pembelajaran tematik diperkenalkan pada guru dan anak didik di TKK St. Skolastika Waeia. Diharapkan melalui penyajian video pembelajaran tematik ini dapat meningkatkan minat dan motivasi anak dalam belajar. Luaran lain dari kegiatan ini adalah laporan akhir kegiatan pengabdian kepada masyarakat.

\section{KESIMPULAN}

Dari hasil pengabdian ini, dapat disimpulkan bahwa melalui penggunaan video pembelajaran berbasis tematik dalam pendampingan belajar anak pada masa pandemi dapat meningkatkan minat dan motivasi belajar anak, mendukung perkembangan belajar anak, membantu guru dalam menemukan referensi pembelajaran kreatif dan inovatif apabila proses pembelajaran tetap dilakukan secara daring.

\section{DAFTAR PUSTAKA}

Ardianto, Ifan. (2015). Efektivitas Media Video Pembelajaran "Rumahku” terhadap Aktivitas dan Hasil Belajar Siswa Kelas B di TK RA Perwanida Boyolali. Skripsi. Fakultas IImu Pendidikan. Jurusan Kurikulum danTeknologi Pendidikan. Universitas Negeri Semarang. 
Dadan, Suryana. (2021). Pengembangan Video Pembelajaran Tematik Anak Usia Dini 5-6 Tahun Berbasis Kearifan Lokal. Diakses dari https://www.researchgate.net/publication/353897827 Pengembangan Media Video Pe mbelajaran Tematik Anak Usia Dini 5-6 Tahun Berbasis Kearifan Lokal pada 19 Oktober 2021

Dewi, L. M. I., \& Rimpiati, N. L. (2015). Efektivitas Penggunaan Media Pembelajaran Video Interaktif dengan Setting Diskusi Kelompok Kecil untuk Meningkatkan Keterampilan Berpikir Kritis pada Anak Usia Dini. JEPUN: Jurnal Pendidikan Universitas Dhyana Pura.

Ita, Efrida. (2018). Manajemen pembelajaran pendidikan anak usia dini di TK Rutosoro kecamatan Golewa kabupaten Ngada Flores nusa Tenggara Timur. Jurnal Dimensi Pendidikan dan Pembelajaran Universitas Muhammadiyah Ponorogo, Vol 6, No 1: Halaman 45-52.

Peraturan Menteri Pendidikan dan Kebudayaan Nomor 137. (2014). Standar Tingkat Pencapaian Perkembangan Anak. Jakarta: Permendikbud

Riyanto, Y. (2010). Metodologi Penelitian Pendidikan. Surabaya: Penerbit SIC

Rosdiani, A. Lutfia. (2021). Pembelajaran Tematik di Masa Pandemi Covid-19 (Studi Kasus Pembelajaran Tematik pada Kelas 3 di MI Modern Al-Azhary Ajibarang. Diakses dari http://repository.iainpurwokerto.ac.id/10751/1/COVER BAB\%20I BAB\%20V DAFTAR \%20PUSTAKA.pdf pada 19 Oktober 2021

Syafi'i, Imam, dkk. (2020). Penerapan Video Pembelajaran Daring Anak Usia Dini pada Masa Pandemi Covid-19. Diakses dari http://ejournal.radenintan.ac.id/index.php/alathfaal/article pada 19 Oktober 2021

Yudianto, A. (2017). Pemanfaatan Video sebagai Media Pembelajaran. Retrieved from http://eprints.ummi.ac.id/id/eprint/354 